Conclusions. In the studied sample of barley cultivars, the ranking by 1000-kernel weight and test weight did not change from year to year, indicating a strong role of the genotype in the control of these parameters. An increase in the 1000-kernel weight and test weight is possible with optimal watering during the development phases from emerging to filling.

The variability of the 1000-kernel weight was weak or medium; the variability of the test weight was very weak, also indicating a strong genetic control of these parameters.

Key words: test weight, brewing barley, variability, variation, correlation, genotype, influence of weather conditions

\title{
A FEATURE COLLECTION OF LENTIL (LENS CULINARIS MEDIK.) BY NUTRITIOUS VALUE OF SEEDS
}

Vus N.A., Bezuglaya O.N., Kobyzeva L.N., Bozhko T.N., Vasilenko A.A., Shelyakina T.A. Plant Production Institute named after V.Ya. Yuriev of NAAS, Ukraine

The results of studying the nutritional qualities of a basic collection of lentil (Lens culinaris Medik.) of the National Center for Plant Genetic Resources of Ukraine (NCPGRU) are presented. A feature collection was compiled by nutritional value of seeds. The collection consists of 160 accessions (macrosperma - 57, microsperma - 103). The nutritional qualities of lentil seeds were evaluated by the following parameters: protein content, cooking rate, palatability, cotyledon color, seed coat color, resistance to infuscation, and seed size.

Key words: lentil, collection, nutritional value, cooking properties, cotyledon color, seed coat color, protein, seed size

Introduction. Grain legume cultivation is a reliable way to solve the protein problem. In Ukraine, as in many other countries, there is an acute shortage of protein. However, in addition to quantity, the quality of the protein consumed is no less important. Development of new food varieties of major grain legumes, including lentil, is the most important aspect of modern breeding. High-quality effective breeding requires careful selection of starting material. Evaluation of the existing gene pool and structuring it in collections for different purposes is a priority for genebanks around the world.

Literature review. According to FAO data, around 75 million tons of dietary protein are produced annually in the world, if necessary more than 125 million tons. The daily protein intake is $80-90 \mathrm{~g}$, and the global production of animal protein is 4 times lower than the consumption level. Implementation of grain legumes into production is a way to overcome this situation [1]. More than half $(57 \%)$ of the total protein intake by the population are plant products. However, in addition to the amount of protein, its quality is no less important $[2,3]$. In countries that do not suffer from a lack of protein, there are high risks of diseases caused by an unbalanced diet, such as obesity, diabetes mellitus, atherosclerosis, and other non-infectious systemic diseases [4]. The modern food industry is focused on the processing of animal protein, as a source of energy, nutrition and stability of life. However, in recent decades, under the influence of environmental, economic, cultural and health risks, trends have been observed to reduce the consumption of meat per capita and replace it with vegetable protein as a strategy for ensuring the mankind's food and environmental safety [5].

() Н.А. Вус, О.Н. Безуглая, Л. Н. Кобызева, Т.Н., БожкоА.А. Василенко, Т.А. Шелякина. 2020.

ISSN 1026-9959. Селекція і насінництво. 2020. Випуск 117. 
The nutritional value of lentil is associated with its ability to lower cholesterol and lipids in the human body, which reduces the risk of bowel cancer and type 2 diabetes [6]. In addition, lentils have high levels of phenols, flavonoids and tannins $(6.56 \mathrm{mg}$ equivalent of gallic acid/g), 1.30 and $5.97 \mathrm{mg}$ equivalent of catechin/g, respectively [7]).

Biofortification (bio-enrichment) of food products with necessary microelements both by biotechnological methods and via classical breeding is an important direction of modern breeding. The protein content in lentil seeds positively correlates with the contents of iron and zinc. ICARDA scientists have created lentil varieties with increased contents of iron and zinc. Screening of genetic resource collections to identify sources of increased protein content is an important prerequisite for further development of this breeding avenue [8].

As to the nutritional properties, biochemical composition and substantiality of seeds, lentil ranks the first among legumes and is characterized by good palatability and technological qualities. It is recommended for everyday, infant, vegetarian and medical nutrition [9]. The chemical composition of the seeds is such that 87 grams of seeds are able to provide a person with the following daily intakes of nutrients: $2 \%$ of oil, $14 \%$ of carbohydrates, $36 \%$ of dietary fiber, $95 \%$ of folic acid, $40 \%$ of iron, $25 \%$ of vitamin A1, and $25 \%$ of vitamin PP. Lentils contain significant amounts of prebiotics such as raffinose oligosaccharides, polysaccharides, monosaccharides, and resistant starch, which positively affect human health [10].

As to the content of essential amino acids, the lentil protein corresponds to the standard chicken egg protein (chemical score method) by $88.1 \%$ and to the FAO/WHO's reference protein (amino acid score method) by $116.7 \%$ [11].

The total production of lentils in the world is 7.59 million tons from 6.58 million hectares, with an average yield of 1.15 t/ha [12]. In 2019 in Ukraine, the gross collection of lentil amounted to 8.4 thousand tons from 7.3 thousand ha, with an average yield of $1.07 \mathrm{t} / \mathrm{ha}$ [13].

Lentil breeding in Ukraine is carried out to a very limited extent by few experimental stations. The National Center for Plant Genetic Resources of Ukraine (NCPGRU), where since 1992 the basic collection of lentils has been built up, investigated and maintained, is the main center for lentil studies. At the present, the NCPGRU's lentil collection totals 1,095 accessions. Grain legume gene pool accessions are used by breeders to create new varieties [14].

As part of the solution to the problem, results of multi-year studies and data on the nutritional qualities of lentil accessions of the basic collection were analyzed and summarized, which was the primary objective of our research.

Materials and methods. The field trials were conducted in the scientific crop rotation of the Plant Production Institute named after V.Ya. Turiev of NAAS (PPI NAAS) in the Laboratory of Genetic Resources of Grain Legumes and Groats Crops. Winter wheat was the forecrop. The measurement plot area was $1 \mathrm{~m}^{2}$, without replications; the sowing arrangement was $15 \mathrm{x} 10 \mathrm{~cm}$. Seeds were sown by manual planters within the optimal timeframe. Check accessions were sown every 20 plots.

The Lens culinaris Medik. accessions under investigation were represented by two subspecies: subsp. microsperma (1000-seed weight $<45 \mathrm{~g}$ ) and subsp. macrosperma (1000-seed weight $\geq 45 \mathrm{~g}$ ). The macrosperma check accession - variety Krasnohradska 49; the microsperma check accession - Stepnaya 244.

Over the period of 1992-2018, 555 lentil accessions of the NCPGRU's basic collection have been studied. Each accession was studied during three field seasons.

The collection lentil accessions were investigation in compliance with the "Guidelines for Research into the Genetic Resources of Grain Legumes" [15]. The morphological description and classification of the accessions by their economic and biological features were performed according to the Classifier of the genus Lens L. [16].

Lentil seeds were biochemically analyzed in the Laboratory of Genetics, Biotechnology and Quality, PPI NAAS. The protein content was determined by the Kjeldahl digestion [17]. The cooking properties of lentil seeds were assessed according to the "Methodological guidelines" [18]. Organoleptic assessment was performed according to the classifier [16]. 
The experimental data were statistically processed on a personal computer using the licensed software package Microsoft Word and Microsoft Office Excel (license number 44208338, release date 06/27/2008), Statistics 6.0 (license number BXXR502C631824NET3).

Results and discussion. The primary objective of studies on accessions from collections of genetic resources is assessments of valuable economic, breeding and other characteristics; identification of sources and donors of these characteristics and formation of collections (basic, core, doublet, feature, genetic, special, educational, working).

In a feature collection, accessions are selected according to certain level of phenotypic expression of individual features or their combinations. A feature collection contains accessions selected by a certain level of phenotypic expression of individual features or their combinations and is built up in accordance with a taxon classifier using reference accessions [19].

Domestic lentil varieties have a narrow genetic base and are categorized by to the ecogeographical principle into three main groups, according to the three main regions of the crop cultivation: subtropical (South Asian: India, Nepal, Pakistan, Afghanistan), Mediterranean (Southern Europe and North Africa) and northern temperate (Canada and the USA) [20]. A considerable diversity of accessions in a feature collection covering the entire range of ecogeographical zones, will enable selecting accessions that are as distant from each other as possible to expand the genetic base of new varieties.

The nutritional properties of lentil seeds are evaluated in the phase of full ripeness by the following characteristics: protein content, cooking rate, palatability, cotyledon color, seed coat color, resistance to infuscation, and seed size.

Protein and its content in seeds are major factors that determine the nutritional and feed value of grain legumes. Lentil proteins mainly accumulate in cotyledons and comprise low contents of sulfur-containing amino acids [9].

Lentil proteins are $70 \%$ of globulins, $11 \%$ of glutelins and $3 \%$ of prolamins [7]. In terms of protein content, lentil is second only to soybean and lupine [21]. The protein content in seeds is important both for food and for feed accessions.

According to the "protein content in seeds" trait, the collection consists of accessions:

- With a very high protein content (>30\%) - 1 accession, reference accession UD0600398 (Ukraine); the protein content averaged $30.34 \%$ across the study years;

- With a high protein content (29-30\%) - 26 accessions: Merdzhi (Azerbaijan); Aproszemu sarga (Hungary); Beluga (Israel) and others. Reference accession - Merdzhi (Azerbaijan), with the average protein content of 29.59\%;

- With a medium protein content (26-28\%) - 55 accessions: Dwarf, Asia minor (Slovakia); LUG 77/06 (Ukraine) and others. Reference accession - Asia minor (Slovakia), with the average protein content of $27.08 \%$;

- With a low protein content (20-25\%) - 79 accessions: Liubava, LUG 125/03; Rassvet (Ukraine) and others. Reference accession - Massor (Pakistan), with the average protein content of $23.74 \%$.

For lentil varieties that are grown for food, it is important to evaluate the cooking properties of seeds, which include the cooking rate, coefficient and time. The cooking rate of legume seeds is a varietal trait $[22,23]$, therefore, the success of breeding for this trait is largely determined by starting material - accessions with a high cooking rate of seeds. The cooking time of seeds characterizes the suitability of an accession for using in food: the shorter the cooking time, the more valuable the accession for making soups, salads and groats is [1].

A three-year study of the cooking rate of 555 accessions showed that the lentil accessions had less variable cooking coefficients and were boiled faster than seeds of other legumes. 154 accessions were included in the collection with three gradations of this parameter according to the classifier:

- With very good cooking time ( $<40$ minutes) - 45 accessions: Synychka; Gorlitsa (Ukraine); 1826 S 3 (Canada) and others. Reference accession - 1826 S 3 (Canada), with the cooking time of 24 minutes; 
- With good cooking time (40-60 min.) - 89 accessions: Luhanchanka, 49 Krasnohradska, Linza (Ukraine) and others. Reference accession - Luhanchanka (Ukraine) with the cooking time of 50 minutes;

- With medium cooking time (61-80 min.) - 20 accessions: Liubava, Svitanok, LUG 448/04 (Ukraine) and others. Reference accession - LUG 448/04 (Ukraine), with the cooking time of 75 min.

Our collection includes $29 \%$ of local samples of different origin, which are an important link in improving the nutritional quality of lentil breeding varieties. For example, Ninou et al. [23] in their experiments noted a decrease in the cooking rate of seeds with a parallel increase in the yield when local varieties were involved into the crossbreeding design.

The palatability of seeds is assessed organoleptically during the cooking rate test. The following parameters are assessed: the overall taste of seeds, consistency (oily, crumbly), and toughness of the seed coat. Reference accessions for various levels of the lentil palatability have been distinguished and included in this collection:

- Very low (3 points): LUG 330/04 (Ukraine);

- Low (5 points): 1743 T 19 (Canada);

- High (7 points): Miledi (Russia).

The appearance of seeds is an important aspect of the market value of food lentil: seed coat color, cotyledon color, resistance to infuscation.

In domestic lentil (Lens c. Medik.) varieties, cotyledons can be in 3 colors: yellow, red (orange) or green. The preference for a particular type of lentil in each country depends on local traditions of cultivation and nutrition. Red lentils occupy the maximum volumes on the global market; peeled seeds are consumed in Egypt, West Asia, Sri Lanka, Pakistan, India, and Bangladesh [24]. On the agricultural market, lentils are mainly red (about $75 \%$ of the gross production); green lentils account for 20\%; and others - up to 5\%. The USA and Canada are the main producers of green lentils, while the rest of the world grows mainly red lentils [25]. The cotyledon color is a constant feature, which must be used to identify varieties. The cotyledon color is determined by three genes: Y - yellow, Dg - dark green, B - brown. The dominant combination of BBYY genes determines the orange pigmentation of cotyledons; the recessive alleles of these genes $(y y b b)$ - light green [26]. Ye.I. Barulina and Ye.A. Dombrowskaya theorized that the orange color of cotyledons was dominant, and the green color - recessive [27]. The cotyledon color is important for accessions used for soups and groats. Of hulled seeds, varieties with orange (red) cotyledons are most popular. Hulled seeds are is easier to cook, but they lose flavor.

Slinkard A.E. describes the inheritance of the cotyledon pigmentation in lentil as follows: $y c$ - yellow cotyledons; $Y c$ - red (orange) cotyledons; $i-y c$, an inhibitor of the cotyledon pigmentation alleles (green cotyledons), while $I-y c$ does not inhibit either $y c$ or $Y c$. The red pigmentation is monogenically dominant over the yellow color, and the yellow pigmentation over the green color. The green color is the result of a recessive allele that inhibits any pigmentation, both yellow and orange, and the dominant allele of this gene inhibits neither [28].

The red color of cotyledons is intrinsic to wild species such as L. tomentosus. In interspecies hybridization, it is inherited monogenically and is dominant over the yellow pigmentation [24].

We grouped the accessions by the "cotyledon color" as follows:

- Yellow cotyledons - 87 accessions: Svitanok, Linza, Gorlitsa (Ukraine) and others;

- Orange cotyledons - 67 accessions: LUG 116/09, LUG 124/09, Synychka (Ukraine) and others;

- Green cotyledons - 6 accessions: Zelyonaya Akhunskaya; Zelyonyy Chervonets (Ukraine); Anfiya (Russia).

Thus, each accession with the identified color of cotyledons can be its donor, and, correspondingly, included in specialized breeding programs.

The seed coat color is an important economic feature. The seed coat in lentil can be in four primary colors: gray, brown, green, and black. The rest are their derivatives. The black pigmentation gene (Blt) is dominant and blocks the expression of other pigmentations of the seed 
coat. The green color is determined by the $D g$ gene [29]. Ye.I. Barulina and Ye.A. Dombrovskaya's genetic studies showed that simple alternative traits (color of seedlings, flowers, pods, seeds, cotyledons) in different varieties are inherited by Mendelian rules, regardless of origin. They revealed genes that determine these usual qualitative traits [27]. According to their theory, the black pigmentation of the seed coat with a speckled pattern dominates.

According to the classifier, at present, the genus Lens [16] has eight types of the seed coat pigmentation. In our collection, these types are represented by reference accessions: white color LUG 45/09 (Ukraine); pink - LUG 116/09 (Ukraine); green - Zelyonyy Chervonets (Ukraine); yellow-green - Krasnohradska 250 (Ukraine); gray - 1743 T 19 (Canada); gray-red - Elista (Slovakia); brown - UD0600444 (Ethiopia); black - Beluga (Israel).

It should be noted that the seed coat color types specified in the classifier differ from the categorization of lentil varieties into market classes. Thus, the following classes are distinguished: extra-small red (1000-seed weight $=26 \mathrm{~g})$ and small $(1000$-seed weight $=40 \mathrm{~g})$, with the main consumers being Bangladesh, Pakistan, Egypt, South Asia, the Middle East and northern Africa; small green (1000-seed weight $=29 \mathrm{~g})$ is preferred in Morocco, Greece, Italy, Egypt, and Mexico; medium-sized green (1000-seed weight $=43 \mathrm{~g}$ ), which is popular in northwestern Europe, Spain, Algeria, and USA; large green (1000-seed weight about 60 g), which is in demand in northwestern and southern Europe, South and Central America; dark green speckled (1000-seed weight $30 \mathrm{~g}$ ), with the main consumer being France [10].

The primary pigmentation of the seed coat in the majority of the market lentil classes is determined by two independent genes: gray primary color $(G g c)$ and brown primary color $(\mathrm{Tgc})$ [30]. The dominant and recessive allelic combinations of these two genes result in a brown (Ggc $\mathrm{Tgc}$ ), gray $(\mathrm{Ggctgc})$, brown $(\mathrm{ggc} \mathrm{Tgc})$, or green $(\mathrm{ggc} \operatorname{tgc})$ seed coat and specify the market classes. The homozygous recessive tan gene is epistatic to the $T g c$ gene, but not to the $G g c$ gene [30]. In the tan genotype, expression of the dominant $G g c$ allele leads to the formation of a matte gray seed coat, while the recessive $g g c$ allele causes a clear seed coat. Lentil accessions with the tan gene do not discolor during storage [31] or cooking. A thinner seed coat increases the cooking rate, simplifies decortication and makes seeds look well-rounded. These characteristics increase the value of such accessions for consumers, and their market prices are higher. However, the thin coat of seeds means a greater damage upon harvesting, which reduces germination, but these negative features are eliminated by pre-sowing inoculation [32].

Lentil is more easily changes the seed color than other legumes due to infuscation because of tannins in the seed coat. Infuscation resistance is attributed to no tannins in the seed coat at all. This trait is controlled by one recessive tan tan gene. [33, 34].

Phenolic compounds, which are synthesized in the seed coat of browning lentils, have antioxidant properties and are absent in non-browning accessions. Phenolic compounds such as myricetin, dihydromiricetin, flavantriol and proanthocyanidin are synthesized only in infuscating lentils [32]. The market lentil class known as "tannin-free" or "non-browning/infuscating" exists due to the expression of one recessive tan gene $[33,35]$.

Phenolic compounds can provide antioxidant benefits for human health, and foods such as lentils can be valuable dietary sources of different subclasses of these secondary metabolites. Mirali analyzed phenolic profiles in lentil genotypes with four different colors of the seed coat (green, gray, yellow-brown and brown) and two cotyledon colors (red and yellow) and found that the phenolic compound levels in lentil seeds varied depending on the seed color. The seed coat in lentil genotypes with the homozygous recessive $\operatorname{tg} c$ allele (green and gray seed coat) had higher values of proanthocyanidins and some flavonols. This suggests that lentils with green and gray seed coat may be more promising for a healthy diet [36].

Given the seed coat ability to infuscate, reference accessions were identified:

- Infuscating: Krasnohradska 250 (Ukraine);

- Non-infuscating: LUG 45/09 (Ukraine).

Small-seeded lentils are generally used for groats. Seeds of such accessions are so small (1000-seed weight $<40 \mathrm{~g}$ ) that they do not need to be crushed like peas. Accessions with large seeds (1000-seed weight $>60 \mathrm{~g}$ ) can be used for dishes from whole non-decorticated lentils. 
Thus, the seed size is an important feature characterizing the use of lentils in cooking. In lentils, unlike other grain legumes, there is no negative correlation between the seed size and protein content, which increases its economic value [34].

Reference accessions were chosen for this trait:

- With large seeds (1000-seed weight 61-80 g): Linza (Ukraine);

- With medium seeds (41-60 g): L 135 (Russia);

- With small seeds (21-40 g): Synychka (Ukraine).

Multi-year studies of lentil genetic resources in the Laboratory of the Genetic Resources of Grain Legumes and Groats Crops have resulted in building up a feature collection of lentils by nutritional value of seeds (Certificate No. 286 of December 24, 2019), which consists of 160 accessions (macrosperma - 57, microsperma - 103). The collection accessions cover all geographical regions of the world (Asia (12\%), America (12\%), Africa (16\%) and Europe (60\%)) and representatively reflect the composition of the NCPGRU's basic collection of lentils. The collection contains accessions from 27 countries, with Ukrainian accessions prevailing (23\%).

Conclusions. Our studying the NCPGRU's lentil gene pool allowed us to gain more detailed information on its nutritional value and to build up a feature collection, representing the genetic diversity of the species Lens culinaris Medic. by the investigated traits. This collection will facilitate the selection of starting material for specialized breeding programs to create new food varieties.

\section{References}

1. Kyrychenko VV, Kobyzeva LN, Bezugla OM, Ryabchun VK, Sokol TV, Bozhko TM. The gene pool of lentils in Ukraine. Kharkiv: NAAS, Plant Production Institute nd a VYa Yuriev, 2016. 202 p.

2. Roy S, Hussain SA. Protein deficiency: challenges and means to fight. Acta Scientific Nutritional Health. 2018; 2(12): 01-02. URL: https://www.actascientific. com/ASNH/pdf/ASNH-02-0139.pdf.

3. Semba RD. The rise and fall of protein malnutrition in global health. Ann. Nutr. Metab. 2016; 69(2): 79-88. DOI: 10.1159/000449175.

4. Saskatchewan Pulse Growers. Saskatchewan Pulse Growers: 2020. [cited 2020 May 07]. URL: http://www.saskpulse.com/.

5. Aiking H. Future protein supply (Review). Trends in Food Science \& Technology. 2011; 22: 112-120. URL: DOI:10.1016/j.tifs.2010.04.005.

6. Roy F, Boye JI, Simpson BK. Bioactive proteins and peptides in pulse crops: Pea, chickpea and lentil. Food Research International (Ottawa, Ont.) 2010; 43(2): 432-442. DOI: 10.1016/j.foodres.2009.09.002 AGR: IND44322587.

7. Jarpa-Parra M. Lentil protein: a review of functional properties and food application. An overview of lentil protein functionality. International Journal of Food Science and Technology. 2018; 53: 892-903. DOI: https://doi.org/10.1111/ijfs.13685.

8. Garg M, Sharma N, Sharma S, Kapoor P, Kumar A, Chunduri V, Arora P. Biofortified crops generated by breeding, agronomy, and transgenic approaches are improving lives of millions of people around the World. Front. Nutr. 2018; 5: 12. DOI: 10.3389/fnut.2018.00012.

9. Khazaei H, Subedi M, Nickerson M, Martínez-Villaluenga C, Frias J, Vandenberg A. Seed protein of lentils: current status, progress, and food applications. Foods. 2019; 8: 391. DOI: 10.3390/foods 8090391.

10. Johnson CR, Thavarajah D, Combs GF, Thavarajah P. Lentil (Lens culinaris L.): A prebioticrich whole food legume. Food Research International. 2013; 51: 107-113. DOI: 10.1016/j.foodres.2012.11.025.

11. Bosak VN, Sachyvko TV. Peculiarities of amino acid composition and biological value of legume vegetable protein. Vestnik Belorusskoy gosudarstvennoy selskokhoziaystvennoy akademii. 2018; 1: 37-40.

12. FAOSTAT. 2019 [cited 2020 March 20]. URL: http://www.fao.org/faostat/en/. 
13. Production output, yield and harvested area of agricultural crops by types and regions. State Statistics Service of Ukraine. 1998-2019 [cited 2020 May 07]. URL: http://www.ukrstat.gov.ua/operativ/operativ2019/sg/ovuzpsg/Arh_ovuzpsg_2019_u.html.

14. Kobyzeva LN, Bezugla OM, Bezuglyi IM, Riabukha SS, Tertyshnyi OV, Sylenko SI. The effectiveness of valuable sources from the NCPGRU's national collection of grain legumes in breeding practice. Sel. Nasinn. 2011; 100: 172-180.

15. Kobyzeva LN, Bezugla OM, Sylenko SI, Kolotylov VV, Sokol TV, Dokukina KI, Vasylenko AO, Bezuglyi IM, Vus NO. Methodical recommendations for studying the genetic resources of grain legumes. Kharkiv: NAAS, Plant Production Institute nd a VYa Yuriev, 2016. 84 p.

16. International CMEA's classifier of the genus Lens Mill. Leningrad: VIR, 1985. 39 p.

17. Yermakov AI. Methods of biochemical studies on plants. Moscow: Agropromizdat, 1987. $430 \mathrm{p}$.

18. Komarov VI, Proreshneva RK, editors. Technological evaluation of peas, lentils, beans. Methodical recommendations. Leningrad: VIR; 1992. 17 p.

19. Genetic resources of plants. Terms and definitions (National Standard of Ukraine 7066.2009 valid from 01/01/2011). Kyiv: Derzhspozhyvstandart Ukrayiny, 2010.

20. Khazaei H, Caron CT, Fedoruk M, Diapari M, Vandenberg A, Coyne CJ, McGee R, Bett KE. Genetic diversity of cultivated lentil (Lens culinaris Medik.) and its relation to the World's agro-ecological zones. Front. Plant Sci. 2016; 7: 1093. DOI: 10.3389/fpls.2016.01093.

21. Orekhivskyi VD, Sichkar VI, Ovsiannykova LK, Mamatov MO, Solomonov RV. Lentils are a source of vegetable protein. Zernovi produkty I kombikormy. 2017; 17 (4): 22-30.

22. Kobyzeva LN. Starting material for breeding of grain legumes with improved technological parameters of seeds. Faktory experymentalnoyi evoliutsii organizmiv. 2013; 13: 54-57.

23. Ninou E, Papathanasiou F, Vlachostergios DN, Mylonas I, Kargiotidou A, Pankou C, Papadopoulos I, Sinapidou E, Tokatlidis I. Intense breeding within lentil landraces for highyielding pure lines sustained the seed quality characteristics. Agriculture. 2019; 9: 175. DOI: 10.3390/agriculture9080175.

24. Suvorova GN, Ikonnikov AV. Inheritance of the "red cotyledons" trait in lentils upon crossing with the species Lens tomentosus Ladizinsky. Zernobobvyie I krupianyie kultury. 2016; 4(20): $38-41$.

25. Yatchuk PV. Current status of lentil production. Zernobobvyie I krupianyie kultury. 2018; 4(28): 110-112. DOI: 10.24411/2309-348X-2018-11058.

26. Kumar Y, Mishra SK, Tyagi MC, Singh SP, Sharma B. Linkage between genes for colour, plant pubescence, number of leaflets and plant height in lentil (Lens culinaris Medik.). Eyphytica. 2005; 145:41-48. DOI: 10.1007/s10681-005-0103-z.

27. Konovalov YuB. Special breeding of field crops. Moscow: Agropromizdat, 1990. 543 p.

28. Slinkard AE. Inheritance of cotyledon color in lentils. Journal of Heredity. 1978; 69(2): 139140. DOI: 10.1093/ oxfordjournals.jhered.a108901.

29. Emami MK. Genetic mapping in lentil (Lens culinaris Medik.). [dissertation]: Indian Agricultural Research Institute, 1996.

30. Vandenberg A, Slinkard AE. Genetics of seed coat color and pattern in lentil. Journal of Heredity. 1990; 81(6): 484-488. DOI: 10.1093/oxfordjournals.jhered.a111030.

31. Smykal P, Vernoud V, Blair MW, Soukup A, Thompson RD. The role of the testa during development and in establishment of dormancy of the legume seed. Front Plant Sci. 2014; 5: 351. DOI: 10.3389/fpls. 2014.00351 PMID: 25101104.

32. Mirali M, Purves RW, Stonehouse R, Song R, Bett K, Vandenberg A. Genetics and biochemistry of zero-tannin lentils. PLoS ONE. 2016; 11(10): e0164624. DOI: 10.1371/journal.pone.0164624.

33. Vaillancourt R, Slinkard AE, Reichert RD. The inheritance of condensed tannin concentration in lentil. Can J Plant Sci. 1986; 66(2): 241 \pm 6 . DOI: 10.4141/cjps86-038.

34. Amelin AV, Kondykov IV, Ikonnikov AV, Chekalin EI, Kondykova NN, Dmitrieva EA. Genetic and physiological aspects of lentil breeding. Vestnik OrelGAU. 2013; 1 (40): 31-39.

35. Muehlbauer F, Sarker A. Tannin free lentils: A promising development for specialty use and increased value. Grain Legumes. 2011; 56: 27-28. 
36. Mirali M, Purves RW, Vandenberg A. Profiling the phenolic compounds of the four Major seed coat types and their relation to color genes in lentil. J. Nat. Prod. 2017; 80(5): 1310-1317. DOI: 10.1021/acs.jnatprod.6b00872. Epub 2017 Apr 27.

\section{Список використаних джерел}

1. Кириченко В.В., Кобизєва Л.Н., Безугла О.М., Рябчун В.К., Сокол Т.В., Божко Т.М. Генофонд сочевиці в Україні. Харків: НААН, Ін-т рослинництва ім. В.Я. Юр'єва, 2016. $202 \mathrm{c}$.

2. Roy S., Hussain S.A. Protein deficiency: challenges and means to fight. Acta Scientific Nutritional Health. 2018. No 2(12). P. 01-02. URL: https://www.actascientific.com/ASNH/pdf/ASNH-02-0139.pdf.

3. Semba R.D. The rise and fall of protein malnutrition in global health. Ann. Nutr. Metab. 2016. No 69(2). P. 79-88. DOI: 10.1159/000449175.

4. Saskatchewan Pulse Growers. Saskatchewan Pulse Growers: 2020. [cited 2020 May 07]. URL: http://www.saskpulse.com/.

5. Aiking H. Future protein supply (Review). Trends in Food Science \& Technology. 2011. No 22. P. 112-120. URL: DOI:10.1016/j.tifs.2010.04.005.

6. Roy F., Boye J.I., Simpson B.K. Bioactive proteins and peptides in pulse crops: Pea, chickpea and lentil. Food Research International (Ottawa, Ont.) 2010. No 43(2). P. 432-442. DOI: 10.1016/j.foodres.2009.09.002 AGR: IND44322587.

7. Jarpa-Parra M. Lentil protein: a review of functional properties and food application. An overview of lentil protein functionality. International Journal of Food Science and Technology. 2018. No 53. P. 892-903. DOI: https://doi.org/10.1111/ijfs.13685.

8. Garg M., Sharma N., Sharma S., Kapoor P., Kumar A., Chunduri V., Arora P. Biofortified crops generated by breeding, agronomy, and transgenic approaches are improving lives of millions of people around the World. Front. Nutr. 2018. No 5. P. 12. DOI: 10.3389/fnut.2018.00012.

9. Khazaei H., Subedi M., Nickerson M., Martínez-Villaluenga C., Frias J., Vandenberg A. Seed protein of lentils: current status, progress, and food applications. Foods. 2019. No 8. P. 391. DOI: 10.3390/foods8090391.

10. Johnson C.R., Thavarajah D., Combs G.F., Thavarajah P. Lentil (Lens culinaris L.): A prebiotic-rich whole food legume. Food Research International. 2013. No 51. P. 107-113. DOI: 10.1016/j.foodres.2012.11.025.

11. Босак В.Н., Сачивко Т.В. Особенности аминокислотного состава и биологическая ценность белка бобовых овощных культур. Вестник Белорусской государственной сельскохозяйственной академии. 2018. № 1. С. 37-40.

12. FAOSTAT. 2019 [cited 2020 March 20]. URL: http://www.fao.org/faostat/en/.

13. Обсяг виробництва, урожайність та зібрана площа сільськогосподарських культур за їх видами по регіонах. Держстат України. 1998-2019 [cited 2020 May 07]. URL: http://www.ukrstat.gov.ua/operativ/operativ2019/sg/ovuzpsg/Arh_ovuzpsg_2019_u.html.

14. Кобизєва Л.Н., Безугла О.М., Безуглий І.М., Рябуха С.С., Тертишний О.В., Силенко С.І. Ефективність використання цінних джерел національної колекції зернобобових культур НЦГРРУ в селекційній практиці. Селекція і насінництво. 2011. Вип. 100. C. $172-180$.

15. Кобизєва Л.Н., Безугла О.М., Силенко С.І., Колотилов В.В., Сокол Т.В., Докукіна К.І., Василенко А.О., Безуглий I.M., Вус Н.О. Методичні рекомендації 3 вивчення генетичних ресурсів зернобобових культур. Харків: НААН. Інститут рослинництва ім. В.Я. Юр'єва, 2016. 84 с.

16. Международный классификатор СЭВ рода Lens Mill. Ленинград: ВИР, 1985. 39 с.

17. Ермаков А.И. Методы биохимического исследования растений. Москва: Агропромиздат, 1987. 430 с.

18. Комаров В.И., Прорешнева Р.К. Технологическая оценка зерна гороха, чечевицы, фасоли. Методические рекомендации. Ленинград: ВИР, 1992. 17 с. 
19. Генетичні ресурси рослин. Терміни та визначення понять (Національний стандарт України): ДСТУ 7066.2009. Чинний від 2011-01-01. Київ: Держспоживстандарт України, 2010.

20. Khazaei H., Caron C.T., Fedoruk M., Diapari M., Vandenberg A., Coyne C.J., McGee R., Bett K.E. Genetic diversity of cultivated lentil (Lens culinaris Medik.) and its relation to the World's agro-ecological zones. Front. Plant Sci. 2016. No 7. P. 1093. DOI: 10.3389/fpls.2016.01093.

21. Орехівський В.Д., Січкар В.І., Овсянникова Л.К., Маматов М.О., Соломонов Р.В. Сочевиця - джерело рослинного білка. Зернові продукти і комбікорми. 2017. № 17(4). C. 22-30.

22. Кобизєва Л.Н. Вихідний матеріал для селекції зернобобових культур з покращеними технологічними показниками насіння. Фактори експериментальної еволюції організмів. 2013. № 13. С. 54-57.

23. Ninou E., Papathanasiou F., Vlachostergios D.N., Mylonas I., Kargiotidou A., Pankou C., Papadopoulos I., Sinapidou E., Tokatlidis I. Intense breeding within lentil landraces for highyielding pure lines sustained the seed quality characteristics. Agriculture. 2019. No 9. P. 175. DOI: 10.3390/agriculture9080175.

24. Суворова Г.Н., Иконников А.В. Наследование признака «красная окраска семядолей» у чечевицы при скрещивании с видом Lens tomentosus Ladizinsky. Зернобобовые и крупяные культуры. 2016. № 4(20). С. 38-41.

25. Ятчук П.В. Современное состояние производства чечевицы. Зернобобовые и крупяные культуры. 2018. № 4(28). C. 110-112. DOI: 10.24411/2309-348X-2018-11058.

26. Kumar Y., Mishra S.K., Tyagi M.C., Singh S.P., Sharma B. Linkage between genes for colour, plant pubescence, number of leaflets and plant height in lentil (Lens culinaris Medik.). Eyphytica. 2005. No 145. P. 41-48. DOI: 10.1007/s10681-005-0103-z.

27. Коновалов Ю.Б. Частная селекция полевых культур. Москва: Агропромиздат, 1990. 543 с.

28. Slinkard A.E. Inheritance of cotyledon color in lentils. Journal of Heredity. 1978. No 69(2). P. 139-140. DOI: 10.1093/ oxfordjournals.jhered.a108901.

29. Emami M.K. Genetic mapping in lentil (Lens culinaris Medik.). [dissertation]: Indian Agricultural Research Institute, 1996.

30. Vandenberg A., Slinkard A.E. Genetics of seed coat color and pattern in lentil. Journal of Heredity. 1990. No 81(6). P. 484-488. DOI: 10.1093/oxfordjournals.jhered.a111030.

31. Smykal P., Vernoud V., Blair M.W., Soukup A., Thompson R.D. The role of the testa during development and in establishment of dormancy of the legume seed. Front Plant Sci. 2014. No 5. P. 351. DOI: 10.3389/fpls. 2014.00351 PMID: 25101104.

32. Mirali M., Purves R.W, Stonehouse R., Song R., Bett K., Vandenberg A. Genetics and biochemistry of zero-tannin lentils. PLoS ONE. 2016. No 11(10). P. e0164624. DOI: 10.1371/journal.pone.0164624.

33. Vaillancourt R., Slinkard A.E., Reichert R.D. The inheritance of condensed tannin

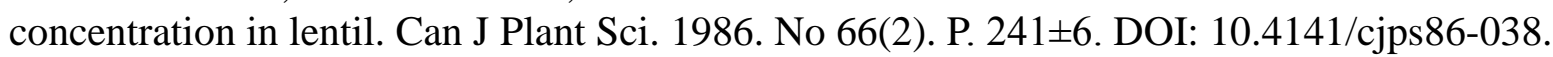

34. Амелин А.В., Кондыков И.В., Иконников А.В., Чекалин Е.И., Кондыкова Н.Н., Дмитриева Е.А. Генетические и физиологические аспекты селекции чечевицы. Вестник ОрелГАУ. 2013. № 1 (40). С. 31-39.

35. Muehlbauer F., Sarker A. Tannin free lentils: A promising development for specialty use and increased value. Grain Legumes. 2011. No 56. P. 27-28.

36. Mirali M., Purves R.W., Vandenberg A. Profiling the phenolic compounds of the four Major seed coat types and their relation to color genes in lentil. J. Nat. Prod. 2017. No 80(5). P. 1310-1317. DOI: 10.1021/acs.jnatprod.6b00872. Epub 2017 Apr 27. 


\section{ОЗНАКОВА КОЛЕКЦІЯ СОЧЕВИЦІ (LENS CULINARIS MEDIK.) ЗА ХАРЧОВОЮ ЦІННІСТЮ НАСІННЯ}

Вус Н.А., Безугла О.М., Кобизєва Л.Н., Божко Т.Н., Василенко А.О., Шелякіна Т.А. Інститут рослинництва ім. В.Я. Юр'єва НААН, Україна

Мета дослідження полягала в узагальненні та аналізі багаторічних даних про харчові якості зразків сочевиці (Lens culinaris Medik.) з базової колекції Національного центру генетичних ресурсів рослин України (НЦГРРУ).

Матеріали і методи. За 1992-2018рр. було вивчено 555 зразків базової колекції сочевиці НЦГРРУ. Зразки виду Lens culinaris Medik. було представлено двома підвидами: subsp. microsperma та subsp. macrosperma.

Вивчення колекційних зразків сочевиці та морфологічний опис зразків, їх класифікацію за господарськими і біологічними властивостями проведено за Класифікатором роду Lens L.

Вміст білка в насінні визначали методом К'єльдаля у лабораторії генетики, біотехнології та якості Інституту рослинництва ім. В. Я. Юр'єва НААН.

Обговорення результатів. Харчові властивості насіння сочевиці оцінювали у фазу повної стиглості за ознаками: вміст білка, час розварювання, смакові якості, колір сім'ядолів, та насіннєвої оболонки, стійкість до побуріння і крупність насіння.

За ознакою «вміст білка в насінні» до колекції включено зразки: із дуже високим рівнем прояву ознаки (понад 30 \%), один зразок еталон UD0600398, Україна вміст білка 30,34 \%; 3 високим (29-30 \%) 26 зразків; із середнім (26-28 \%) 55 зразків; із низьким (20-25\%) 79 зразків. За ознакою «швидкість розварювання» до колекції було включено 154 зразки: із дуже хорошою (менше 40 хвилин) 45 зразків; хорошою (40-60 хв.) 89 зразків; середньою (61-80 хв.) 20 зразків. Виділено еталони різного рівня смакових якостей сочевиці, які було включено до означеної колекції: дуже низька якість (3 бали): ЛУГ 330/04, Україна; низька (5 балів): 1743 Т 19, Канада; висока (7 балів): Миледи, Росія.

Важливим аспектом ринкової вартості харчової сочевиці є зовнішній вигляд насіння: колір насіннєвої оболонки, колір сім'ядолів, стійкість до побуріння. За ознакою «колір сім'ядолів» виділено: із жовтим кольором - 87 зразків, із жовтогарячим - 67 зразків, із зеленим - шість зразків. У відповідності до класифікатору роду Lens на цей час існує вісім типів забарвлення насіннєвої оболонки, еталони якої представлено зразками: біла ЛУГ 45/09, Україна; рожева - ЛУГ 116/09, Україна; зелена - Зелений червонець, Україна; жовто-зелена - Красноградська 250, Україна; сіра - 1743 Т 19, Канада; сірочервона - Elista, Словаччина; коричнева - UD0600444, Ефіопія; чорна - Beluga, Ізраїль.

Враховуючи здатність насіннєвої оболонки до побуріння, виділено зразки еталони за цією ознакою: буріючі - Красноградская 250, Україна; небуріючі - ЛУГ 45/09, Україна.

Ключові слова: сочевиия, колекція, харчова ичінність, розварюваність, колір сім'ядолів та насіннєвої оболонки, стійкість до побуріння, крупність насіння.

\section{ПРИЗНАКОВАЯ КОЛЛЕКЦИЯ ЧЕЧЕВИЦЫ (LENS CULINARIS MEDIK.) ПО ПИЩЕВОЙ ЦЕННОСТИ СЕМЯН}

Вус Н.А., Безуглая О.Н., Кобызева Л.Н., Божко Т.Н., Василенко А.А., Шелякина Т.А. Институт растениеводства им. В.Я. Юрьева НААН, Украина

Цель исследования заключалась в обобщении и анализе многолетних данных о пищевом качестве образцов чечевицы (Lens culinaris Medik.) из базовой коллекции Национального центра генетических ресурсов растений Украины (НЦГРРУ).

Материалы и методы. За 1992-2018 гг. было изучено 555 образцов базовой коллекции чечевицы НЦГРРУ. Образцы вида Lens culinaris Medik. были представлены двумя подвидами: subsp. microsperma и subsp. macrosperma. 
Изучение коллекционных образцов чечевицы и морфологическое описание, их классификация по хозяйственным и биологическим свойствам проведены по Классификатору рода Lens L.

Содержание белка в семенах определяли методом Къельдаля в лаборатории генетики, биотехнологии и качества Института растениеводства им. В.Я. Юрьева НААН.

Обсуждение результатов. Пищевые свойства семян чечевицы оценивали у фазу полной спелости по признакам: содержание белка, время разваривания, вкусовые качества, окраска семядолей и семенной оболочки, устойчивость к побурению и крупность семян.

По признаку «содержание белка в семенах» в коллекцию включены образцы: с очень высоким уровнем проявления признака (выше 30 \%), один образец эталон UD0600398, Украина содержание белка 30,34 \%; с высоким (29-30 \%) 26 образцов; со средним (26$28 \% 55$ образцов; с низким (20-25\%) 79 образцов. По признаку «скорость разваривания» в коллекцию включены 154 образца: с очень хорошей (менее 40 мин) 45 образцов; хорошей (40-60 мин) 89 образцов; средней (61-80 мин) 20 образцов. Выделены эталоны разного уровня пищевого качества чечевицы, включенные в означенную коллекцию: очень низкое качество (3 балла): ЛУГ 330/04, Украина; низкое (5 баллов): 1743 Т 19, Канада; высокое (7 баллов): Миледи, Россия.

Важным аспектом рыночной стоимости пищевой чечевицы является внешний вид семян: окраска семенной оболочки, окраска семядолей, устойчивость к побурению. По признаку «окраска семядолей» выделены: с желтой окраской - 87 образцов, с оранжевой - 67 образцов, с зеленой - шесть образцов. В соответствии с Классификатором рода Lens на это время существуют восемь типов окраски семенной оболочки, эталоны которых представлены образцами: белая - ЛУГ 45/09, Украина; розовая - ЛУГ 116/09, Украина; зеленая - Зелений червонець, Украина; желто-зеленая - Красноградська 250, Украина; серая - 1743 Т 19, Канада; серо-красная - Elista, Словакия; коричневая UD0600444, Эфиопия; черная - Beluga, Ізраиль.

Учитывая способность семенной оболочки к побурению, выделены образцы и эталоны по этому признаку: буреющие - Красноградская 250, Украина; небуреющие - ЛУГ 45/09, Украина.

Ключевые слова: чечевица, коллекция, пищевая цүенность, разваримость, окраска семядолей и семенной оболочки, устойчивость к побурению, крупность семян.

\section{A FEATURE COLLECTION OF LENTIL (LENS CULINARIS MEDIK.) BY NUTRITIOUS VALUE OF SEEDS}

Vus N.A., Bezuglaya O.N., Kobyzeva L.N., Bozhko T.N., Vasilenko A.A., Shelyakina T.A. Plant Production Institute named after V.Ya. Yuriev of NAAS, Ukraine

The study purpose was to summarize and analyze multi-year data on the nutritional quality of lentil (Lens culinaris Medik.) accessions from the basic collection of the National Center for Plant Genetic Resources of Ukraine (NCPGRU).

Materials and methods. In 1992-2018, 555 accessions of the NCPGRU's basic collection of lentils were studied. Lens culinaris Medik. accessions were represented by two subspecies: subsp. microsperma and subsp. macrosperma.

The collection accessions of lentils were investigated and morphologically described; they were grouped by economic and biological features according to the Classifier of the genus Lens L.

The protein content in seeds was determined by the Kjeldahl digestion in the Laboratory of Genetics, Biotechnology and Quality of the Plant Production Institute nd. a. VYa Yuriev NAAS.

Results and discussion. The nutritional parameters of lentil seeds were evaluated in the full ripeness phase: protein content, cooking time, palatability, colors of cotyledons and seed coat, resistance to infuscation, and seed size. 
As to the protein content in seeds, the collection includes the following accessions: with a very high protein content $(>30 \%)$ - one reference accession UD0600398 (Ukraine) with the protein content of $30.34 \%$; with high protein content (29-30\%) - 26 accessions; with medium protein content (26-28\%) - 55 accessions; with low protein content (20-25\%) - 79 accessions. As to the cooking boiling rate, the collection includes 154 accessions: with a very good rate $(<40$ minutes) -45 accessions; with a good rate (40-60 minutes) - 89 accessions; with a medium rate (61-80 minutes) - 20 accessions. Reference accessions for various levels of lentil palatability were distinguished and included in the collection: very low palatability ( 3 points) LUG 330/04 (Ukraine); low palatability (5 points) - 1743 T 19 (Canada); high palatability (7 points) - Miledi, (Russia).

The seed appearance is an important aspect of the market value of food lentils: the seed coat color, cotyledon color, resistance to infuscation. The accessions were grouped by cotyledon color as follows: yellow -87 accessions; hot-yellow -67 accessions; green -6 accessions. In accordance with the Classifier of the genus Lens, there are currently eight types of the seed coat pigmentation; their references are listed below: white - LUG 45/09 (Ukraine); pink LUG 116/09 (Ukraine); green - Zelenyy Chervonets (Ukraine); yellow-green - Krasnohradska 250 (Ukraine); gray - 1743 T 19 (Canada); gray-red - Elista (Slovakia); brown - UD0600444 (Ethiopia); and black - Beluga (Israel).

Given the ability of the seed coat to infuscate, the reference accessions for this trait were chosen: infuscating - Krasnohradska 250 (Ukraine); non-infuscating - LUG 45/09 (Ukraine).

Key words: lentil, collection, nutritional value, cooking properties, cotyledon color, seed coat color, protein, seed size.

\section{ВЛИЯНИЕ ГАБИТУСА РАСТЕНИЙ РАПСА ОЗИМОГО НА ФОРМИРОВАНИЕ ПРОДУКТИВНОСТИ}

Глухова Н.А. ${ }^{1}$, Богуславский Р.Л. ${ }^{1}$, Исаенко А.А. ${ }^{2}$

${ }^{1}$ Институт растениеводства им. В.Я. Юрьева НААН, Украина

${ }^{2}$ Филиал Украинского Института экспертизы сортов растений, Харьковский областной государственный центр экспертизы сортов растений, Украина

В статье рассмотрены различия в формировании продуктивности растениями рапса озимого с цилиндрическим и сферическим габитусом. Установлена тесная зависимость между числом стручков на растении и числом стручков центральной веточки у растений с цилиндрическим габитусом $(\mathrm{r}=0,80)$ и слабая - у растений со сферическим габитусом $(\mathrm{r}=$ $0,49)$. Зависимость между массой семян с растения и с центральной веточки была неоднозначной, отсутствовала $(\mathrm{r}=0,03)$ у растений с цилиндрическим габитусом и была средней $(\mathrm{r}=0,63)$ у растений со сферическим габитусом.

Ключевые слова: рапс озимый, габитус, продуктивность, иентральная веточка, массовая доля семян

Вступление. Н.И. Вавилов в одном из самых значительных своих трудов «Закон гомологических рядов в наследственной изменчивости» писал: «Селекция по существу есть вмешательство человека в формообразование животных и растений; другими слова-

(ㅇ Н.А. Глухова, Р.Л. Богуславский, А.А. Исаенко. 2020.

ISSN 1026-9959. Селекція і насінництво. 2020. Випуск 117. 